\title{
Biochemical Constituents Variation in Resistant and Susceptible Rice Genotypes against Sheath Rot Disease of Rice
}

\author{
S. V. Nalawade ${ }^{1 *}$, P. R. Patel ${ }^{2}$ and V. A. Patil \\ ${ }^{1}$ Department of Plant Pathology, N. M College of Agriculture, Navsari Agricultural \\ University, Navsari-396 450, Gujarat, India \\ ${ }^{2}$ Department of Plant Pathology, ACHF, ${ }^{3}$ Main Rice Research Centre, SWMRU, Navsari \\ Agricultural University, Navsari-396 450, Gujarat, India \\ *Corresponding author
}

\section{A B S T R A C T}

\begin{tabular}{l} 
K e y w o r d s \\
Biochemical \\
constitutions, \\
Sheath rot, \\
Sarocladium \\
oryzae, Resistant \\
and susceptible \\
\hline Article Info \\
Accepted: \\
05 April 2020 \\
Available Online: \\
10 May 2020
\end{tabular}

Six promising entries along with two checks showing resistant and moderately resistan reaction to sheath rot of rice at field during screening of advanced genetic material were analysed for biochemical constituent's changes at pre and post inoculation stage (7 days after inoculation of $S$. oryzae) under pot condition during kharif 2019. The results revealed that, total soluble sugar, reducing sugar, non-reducing sugar, total soluble protein, total phenol and total silica content estimated in rice leaves of all the genotypes were significantly influenced at pre and post inoculation stage. Total soluble sugar, reducing sugar, non-reducing sugar and total soluble protein was recorded 2-4 folds more in highly susceptible genotype (GR-11). It was drastically reduced by $31.33,28.11,35.11$ and 31.12 per cent, respectively over pre inoculated stage in the plants artificially inoculated with $S$. oryzae at 7 days after inoculation, followed by moderately resistant genotypes (NVSR355, NVSR- 2565 and NVSR- 389) and minimum in resistant genotypes (Sambha mahsuri, NVSR-317, NVSR-411 and NVSR-405), respectively. The total phenol and total silica content was 2-3 folds more in highly resistant (Sambha mahsuri, NVSR-317, NVSR411 and NVSR-405) and moderately resistant (NVSR-355, NVSR- 2565 and NVSR-389) genotypes compared to susceptible genotype (GR-11) at 7 days after infection. Therefore, considering all biochemical parameters, NVSR-317, NVSR-405 and NVSR-411 rice genotypes with lower levels of total soluble sugar, reducing sugar, non-reducing sugar and total soluble protein content and higher levels of total phenol and total silica content were found resistant to sheath rot disease induced due to $S$. oryzae as compared with susceptible genotypes.

\section{Introduction}

Rice (Oryza sativa L.) is one of the economically and nutritionally important cereal crop commonly grown as staple food in south Gujarat. Diseases are the major constraint in economic crop production as they impose heavy losses. Among various fungal diseases reported, Sheath rot incited by Sarocladium oryzae (Sawada) W. Games and 
D. Hawksworth is one of the emerging rice diseases and has gained the status of a major disease in rice with yield loss varying from 9.6 to 85 per cent depending on weather factors during the crop growth-period (Phookan and Hazarika, 1992). The pathogen attacks on the uppermost flag leaf sheath before the young panicles emerge. Oblong or irregular brown spots first appear on the flag leaf sheath. The young panicles may continue to exist within the sheath or emerge partly, panicles rot and abundant whitish powdery fungal growth formed inside and outside the leaf sheath.

Plants defend themselves against pathogen challenge by the activation of defense responsive pathways (Staskawicz et al., 1997) and production of defense related antifungal, antibacterial and antiviral biochemicals that are pre-formed (already present in plant tissue in different amounts) or induced following infection-synthesized phytoalexins. Most of the higher plants are a rich storehouse of natural chemicals. like phenols, flavanoids, quinines, tannins, alkaloids, saponins, sterols and terpenoids responsible to play a defensive role in the plants. Such plant chemicals contribute to diverse biological activities such as antimicrobial, allelopathic, antioxidant and bioregulatory properties and these natural products thus can certainly substitute harmful synthetic fungicides for plant disease control. The identification of differences in biochemical events between pre and postinoculated tissue is a prerequisite for understanding the host-pathogen interaction. In rice plant, biochemical studies have to play active role in resistance mechanism of plant to disease and might applied for development of resistant cultivars. Present investigation was therefore, undertaken to estimate certain biochemical parameters viz., total soluble sugar, reducing sugar, non-reducing sugar, total phenol, total soluble protein and total silica content that may be responsible for the characterize resistance and susceptibility of the rice genotypes against sheath rot of rice.

\section{Materials and Methods}

\section{Screening of rice genotypes against sheath rot}

Twenty-nine entries along with three checks were screened by artificial epiphytotics condition under field during Kharif 2018 at the farm of Main Rice Research Centre, NAU, Navsari. The state susceptible check GR-11 was planted after every $10^{\text {th }}$ entry and all around the sheath rot screening nursery. All entries were grown up to booting stage and artificial inoculation of the pathogen was done by single grain insertion method. All the recommended agronomical practices were adopted for raising the crop.

Periodical observations made on incidence and severity of sheath rot of rice, 20 hills per plot were randomly selected and labeled. Per cent disease incidence and intensity were calculated by the formula:

\section{Per cent disease incidence}

Per cent disease incidence was calculated by using formula.

Disease incidence $(\%)=$

Number of diseased plants

Total number of plant observed

\section{Per cent disease severity}

The disease severity was measured by adopting 0-9 scale (Table 1) by using standard evaluation system (SES) for rice developed by International Rice Research Institute, Philippines (IRRI, 2013). Further, the disease severity was calculated using the following formula. 
Sum of the individual disease ratings

Total no. of leaves observed $\times$ Maximum grade $\times 100$

\section{Determinations of biochemical constituents against sheath rot disease}

A pot culture experiment was conducted in completely randomized block design with three repetitions at the Department of Plant Pathology, NAU, Navsari during Kharif 2019. Six promising entries viz., NVSR-317, NVSR-411, NVSR-405, NVSR-355, NVSR2565 and NVSR-389 that observed resistant and moderately resistant at field during screening of advanced genetic material in Kharif-2018 with two checks Samba Mahsuri (Resistant check) and GR-11(Susceptible check) used as test genotypes for determination of various biochemical constituents against sheath rot disease. The pots $(30 \mathrm{~cm}$ diameter) were filled with $25 \mathrm{~kg}$ sterilized autoclaved soil (at $1.2 \mathrm{~kg} \mathrm{~cm}$ for 1 hour for three consecutive days).

Sowing was done in pot by dibbling 20 seeds of each test entry in a pot. When the test entries attained booting stage, one set of genotypes was inoculated with Sarocladium oryzae by single grain insertion method while another set of same genotypes receiving no inoculation was maintained as uninoculated control. Pre-inoculation and post-inoculation (after 7 days of inoculation) leaf samples from different genotypes of rice were collected for biochemical analysis. Changes in the biochemical constituent's viz., total soluble sugar, reducing sugar, non reducing sugar, total soluble protein, total phenol and total silica content induced due to Sarocladium oryzae were analyzed as per standard procedures described in book Standard methods of biochemical analysis by Thimmaiah (1999). Estimation total soluble sugar content was done by Anthrone method as per Hedge and Hofreiter (1962). Reducing sugar was estimated by DNS (Dinitrosalicylic acid) method as per Sadasivam and Manickam (1992) and non-reducing sugar from the rice leaf was estimated by subtracting reducing sugars from total sugars. Total soluble protein was estimated according by method illustrated by Lowry et al., (1951), total phenol content was estimated by FCR method given by Bray and Thorpe (1954) and total silica content at pre-inoculation and post-inoculation (7 DAI) from leaf sample of different rice genotypes was estimated by Microwave Plasma Atomic Emission Spectrometry (MP-AES) method. Statistical analysis of the results were analyzed by simple completely randomized design (CRD) and the critical differences were calculated to assess significance of treatment means wherever the " $F$ " test was found significance at the $5 \%$.

\section{Results and Discussion}

\section{Evaluations of the rice genotypes against sheath rot in field}

In present study, twenty-nine genotypes along with three standard checks were evaluated against sheath rot disease caused by Sarocladium oryzae under the field condition by using artificial inoculation technique during Kharif seasons 2018 at Main Rice Research Center, NAU, Navsari. The advanced generation genotypes screened were grouped by adopting 0-9 scale (Table 1) by using standard evaluation system (SES) for rice into six groups based on their disease reaction scale.

Out of 29 genotypes tested along with three susceptible checks, four genotypes were found resistant whereas, 23 genotypes were found moderately resistant, three genotypes were moderately susceptible and two 
genotypes found susceptible to Sarocladium oryzae under artificial inoculation (Table 2).

\section{Estimation of various biochemical constituents against sheath rot disease of rice}

Six promising entries viz., NVSR-317, NVSR-411, NVSR-405, NVSR-355, NVSR2565 and NVSR-2565 that observed resistant and moderately resistant at field during screening of advanced genetic material in Kharif-2018 with two checks Samba Mahsuri (Resistant check) and GR-11(Susceptible check) used as test genotypes for determination of various biochemical constituents against sheath rot disease.

\section{Estimation of total soluble sugar content}

The data on total soluble sugar content recorded at pre and post inoculation stages ( 7 days after inoculation) presented in table 3 and figure 1 . The results revealed that significant difference existed among the resistant and susceptible genotypes at both stages. A decrease in the total soluble sugars content was observed under infected condition in all the resistant and susceptible rice genotypes.

Among all the genotypes, total soluble sugar content in pre inoculated and inoculated plants were in the range 4.81 to 25.50 and 4.63 to $17.51 \mathrm{mg} / \mathrm{g}$ of fresh weight, respectively. Genotype GR-11 recorded the highest total soluble sugar at pre-inoculated condition (25.50 mg/g fresh weight) and drastically reduced at post inoculated stage (17.51mg/g fresh wt.). It was followed by genotype NVSR-2565 at pre inoculated $(12.73 \mathrm{mg} / \mathrm{g}$ fresh weight) and in inoculated stage $(10.21 \mathrm{mg} / \mathrm{g}$ fresh weight). However, the lowest total soluble sugar was recorded in the genotype NVSR-411 at pre inoculated $(4.81 \mathrm{mg} / \mathrm{g}$ fresh wt.) and reduced in inoculated stage (4.63 mg/g fresh weight) followed by genotype Sambha mahsuri resistant check at pre inoculated $(5.28 \mathrm{mg} / \mathrm{g}$ fresh wt.) and in inoculated stage $(4.82 \mathrm{mg} / \mathrm{g}$ fresh weight).

The mean total sugar was lower in the resistant genotypes at both pre inoculated and inoculated condition (6.94 and $6.15 \mathrm{mg} / \mathrm{g}$ fresh wt.) followed by moderately resistant genotypes (11.33 and $9.29 \mathrm{mg} / \mathrm{g}$ fresh wt.) when compared with total soluble sugars of susceptible genotype at both pre inoculated and inoculated condition (25.50 and 17.51 $\mathrm{mg} / \mathrm{g}$ fresh wt.), respectively.

It was also noted that, total soluble sugar was recorded 2-4 folds more in highly susceptible genotype (GR-11) but it was drastically reduced by 31.33 per cent over pre inoculated in the plants artificially inoculated with $S$. oryzae at 7 days after inoculation followed by moderately resistant $(17.89 \%)$ and minimum $(10.18 \%)$ in resistant genotypes.

\section{Estimation of reducing sugar content}

The results in respect of reducing sugars influenced by sheath rot disease recorded at pre and post inoculation stages ( 7 days after inoculation) presented in table 3 and figure 2 . The data showed the significant difference among the resistant and susceptible genotypes at both stages. A decrease in the reducing sugars content was observed under infected condition in all the resistant and susceptible rice genotypes.

The reducing sugars, ranged between 2.67 to $13.80 \mathrm{mg}$ and 2.56 to $9.92 \mathrm{mg} / \mathrm{g}$ of fresh weight among all the genotypes in pre and post inoculation stages, respectively. Genotype GR-11 recorded the highest reducing sugar $(13.80 \mathrm{mg} / \mathrm{g}$ fresh weight) at pre inoculated condition and it was drastically reduced at post inoculated stage $(9.92 \mathrm{mg} / \mathrm{g}$ 
fresh wt.) followed by genotype NVSR-2565 $(6.58$ and $5.22 \mathrm{mg} / \mathrm{g}$ fresh weight), respectively. However, the lowest reducing sugar was recorded in the genotype NVSR411 at pre inoculated $(2.67 \mathrm{mg} / \mathrm{g}$ fresh wt.) and reduced in inoculated stage $(2.56 \mathrm{mg} / \mathrm{g}$ fresh weight) followed by the resistant check Sambha mahsuri resistant check at pre inoculated $(2.89 \mathrm{mg} / \mathrm{g}$ fresh wt.) and in inoculated stage $(2.67 \mathrm{mg} / \mathrm{g}$ fresh weight).

The mean reducing sugar was lower in the resistant and moderately resistant genotypes (3.48 and $6.01 \mathrm{mg} / \mathrm{g}$ fresh wt.) at pre inoculated and (3.13 and $4.97 \mathrm{mg} / \mathrm{g}$ fresh wt.) inoculated condition, respectively when compared with reducing sugars of susceptible genotype $(13.80$ and $9.92 \mathrm{mg} / \mathrm{g}$ fresh wt), respectively at both the pre inoculated and inoculated conditions.

It was also observed that, reducing sugar was recorded 2-3 folds more in highly susceptible genotype (GR-11) but it was drastically reduced by 28.11 per cent over pre inoculated in the plants artificially inoculated with $S$. oryzae at 7 days after inoculation followed by moderately resistant $(17.07 \%)$ and minimum $(9.20 \%)$ in resistant genotypes.

\section{Estimation of non-reducing sugar content}

The observations on non-reducing sugars were recorded by difference between total sugars and reducing sugars yielded the nonreducing sugars and are presented in table 3 and figure 3. It was evident that significant difference existed among the resistant and susceptible genotypes at both stages. Decrease in the non-reducing sugars content was observed under infected condition in all the resistant and susceptible rice genotypes.

Non-reducing sugars content among all the genotypes was in the range of 2.14 to 11.69 $\mathrm{mg}$ and 2.08 to $7.59 \mathrm{mg} / \mathrm{g}$ of fresh weight in pre inoculated and inoculated plants, respectively. Genotype GR-11 recorded the highest non-reducing sugar content at pre inoculated condition $(11.69 \mathrm{mg} / \mathrm{g}$ fresh weight) and it was drastically reduced at post inoculated stage $(7.59 \mathrm{mg} / \mathrm{g}$ fresh wt.) followed by genotype NVSR-2565 (6.15 and $4.99 \mathrm{mg} / \mathrm{g}$ fresh weight) at both condition, respectively. However, the lowest nonreducing sugar was recorded in the genotype NVSR-411 at pre inoculated $(2.14 \mathrm{mg} / \mathrm{g}$ fresh wt.) and reduced in inoculated stage (2.08 $\mathrm{mg} / \mathrm{g}$ fresh weight) followed by the resistant check Sambha mahsuri resistant check at pre inoculated (2.39 mg/g fresh wt.) and in inoculated plants $(2.14 \mathrm{mg} / \mathrm{g}$ fresh weight).

The mean non-reducing sugar content was lower in the resistant and moderately resistant genotypes (3.46 and $5.32 \mathrm{mg} / \mathrm{g}$ fresh wt.) at pre inoculated and $(3.02$ and $4.32 \mathrm{mg} / \mathrm{g}$ fresh wt.) at post inoculated condition when compared with non-reducing sugars of susceptible genotype (11.69 and $7.59 \mathrm{mg} / \mathrm{g}$ fresh wt.) at both condition, respectively.

It was also founded that, non-reducing sugar was recorded 2-3 folds more in highly susceptible genotype (GR-11) but it was drastically reduced by 35.11 per cent over pre inoculated in the plants artificially inoculated with $S$. oryzae at 7 days after inoculation followed by moderately resistant $(18.85 \%)$ and minimum in (11.07\%) in resistant genotypes.

The higher total, reducing and non-reducing sugars indicate that susceptible genotypes might have more efficient sugar synthesizing capacity that might be supporting the mycelium growth and sporulation. Moreover, availability of lower sugar content in the resistant varieties may be responsible for the inhibition of the growth and multiplication of the pathogen. 


\section{Estimation of total phenol content}

Results on the total phenols recorded at pre and post inoculation stage (7 days after inoculation) are presented in table 4 and figure 4. Significant difference existed among the resistant and susceptible genotypes at both stages. There was increase in the total phenol content under infected condition in all the resistant and susceptible rice genotypes.

Total phenol among the rice genotypes were found in the range of 0.70 to $1.52 \mathrm{mg} / \mathrm{g}$ and 0.82 to $2.16 \mathrm{mg} / \mathrm{g}$ of fresh weight in pre and post inoculation stage, respectively. Significant increase in total phenol content after 7 days of inoculation of S. oryzae was recorded in Sambha mahsuri genotype from 1.52 to $2.16 \mathrm{mg} / \mathrm{g}$ fresh wt. followed by genotype NVSR-411 (1.45 to $2.02 \mathrm{mg} / \mathrm{g}$ fresh weight). However, the lowest total phenol content $(0.70 \mathrm{mg} / \mathrm{g}$ fresh wt. $)$ was recorded in the genotype GR-11 at pre inoculated stage and $(0.82 \mathrm{mg} / \mathrm{g}$ fresh weight $)$ at post inoculated stage followed by genotype NVSR-2565 at pre inoculated $(0.76 \mathrm{mg} / \mathrm{g}$ fresh wt.) and $(0.89 \mathrm{mg} / \mathrm{g}$ fresh weight $)$ in inoculated stage.

The mean total phenol content (1.38 and 0.97 $\mathrm{mg} / \mathrm{g}$ fresh wt.) was maximum in the resistant and moderately resistant genotypes at pre inoculated and at post inoculated condition (1.87 and $1.17 \mathrm{mg} / \mathrm{g}$ fresh wt.) when compared with total phenol content of susceptible genotype $(0.70$ and $0.82 \mathrm{mg} / \mathrm{g}$ fresh wt.), respectively

It was also noted that, there was increase in the per cent mean total phenol content at post inoculated condition in resistant $(35.92 \%)$ and moderately resistant (20.33\%) genotypes as compared to susceptible genotypes $(15.73 \%)$ respectively.

The total phenol content was 2-3 folds more in highly resistant (Sambha mahsuri, NVSR-
411 and NVSR-317) and moderately resistant (NVSR-355, NVSR- 389) genotypes compared to susceptible genotype (GR-11) at 7 days after infection.

The higher level of total phenol may indicate that, the activation of host defensive system or rapid rate of their synthesis induced by the pathogen leading to tissue necrosis may be responsible for the inhibition of the growth and multiplication of the pathogen.

\section{Estimation of total soluble protein content}

The observations on total soluble protein recorded at pre and post inoculation stages (7 days after inoculation) are presented in table 4. and figure 5. From results, it was evident that significant difference existed among the resistant, moderately and susceptible genotypes at both stages. Decrease in the total soluble protein content was observed under infected condition in all the resistant and susceptible rice genotypes.

Total soluble protein content was ranged in between 9.13 to $17.10 \mathrm{mg} / \mathrm{g}$ and 8.50 to $12.61 \mathrm{mg} / \mathrm{g}$ of fresh weight in pre and post inoculation plants among all the genotypes, respectively. Susceptible genotype GR-11 recorded the highest amount of total soluble protein $(17.10 \mathrm{mg} / \mathrm{g}$ fresh weight) at preinoculated condition than rest of genotypes. There was drastic reduction in total soluble protein content $(11.78 \mathrm{mg} / \mathrm{g}$ fresh wt.) as result of inoculation of $S$. oryzae followed by genotype NVSR-2565 $(15.19 \mathrm{mg} / \mathrm{g}$ fresh weight) in pre inoculated to $(11.70 \mathrm{mg} / \mathrm{g}$ fresh weight) in inoculated stage. However, the lowest total soluble protein $(9.13 \mathrm{mg} / \mathrm{g}$ fresh wt.) was recorded in the genotype NVSR-411 at pre inoculated and $(8.50 \mathrm{mg} / \mathrm{g}$ fresh weight) at post inoculated stage followed by Sambha mahsuri genotype as resistant check $(9.20 \mathrm{mg} / \mathrm{g}$ fresh wt.) at pre inoculated and $(8.37 \mathrm{mg} / \mathrm{g}$ fresh weight) at post inoculated stage 
The mean total soluble protein was lower (10.21 and $15.13 \mathrm{mg} / \mathrm{g}$ fresh wt.) in the resistant genotypes at pre inoculated condition and $(9.00$ and $12.13 \mathrm{mg} / \mathrm{g}$ fresh wt.) in moderately resistant genotypes at post inoculated condition when compared with total soluble protein $(17.10$ and $11.78 \mathrm{mg} / \mathrm{g}$ fresh wt.) of susceptible genotype respectively.

There was a decrease in the per cent mean total soluble protein content as result of inoculation of S. oryzae in resistant (11.65\%) and moderately resistant genotypes $(16.07 \%)$ as compared to susceptible $(31.12 \%)$ genotypes, respectively.

The total soluble protein was 2-3 folds more in highly susceptible genotype (GR-11) compared to resistant and moderately resistant genotypes at 7 days after inoculation.

The decrease in protein content might be attributed to their hydrolysis to simpler forms by fungal proteolytic enzymes.

\section{Estimation of total silica content}

Results on total silica content recorded at pre and post inoculation stages ( 7 days after inoculation) are presented in table 4 and figure 6. It was evident that significant difference existed among the resistant and susceptible genotypes at both stages. There was increase in the total silica content was observed under infected condition in all the resistant and susceptible rice genotypes.

With regard to the content of total silica among the rice genotypes, the range was 3.15 to 3.71 and 3.25 to 4.02 per cent in pre inoculated and inoculated plants, respectively. Genotype Sambha mahsuri recorded the highest total silica content at pre-inoculated condition $(3.71 \%)$ and at post inoculated stage $(4.02 \%)$ followed by genotype NVSR-411 in both pre inoculated $(3.65 \%)$ and in inoculated stage $(3.93 \%)$. However, the lowest total silica content was recorded in the genotype GR-11 at pre inoculated (3.15\%) and inoculated stage (3.25\%) followed by genotype NVSR-2565 at pre inoculated $(3.28 \%)$ and in inoculated stage $(3.42 \%)$.

The mean total silica content was more in the resistant and moderately resistant genotypes, at both pre inoculated (3.64 and 3.39\%) and at post inoculated condition (3.89 and $3.56 \%$ ) when compared with total silica content of susceptible genotype (3.15 and 3.25\%), respectively.

It was also noted that, there was increase in the per cent mean total silica content at post inoculated condition in resistant, moderately resistant and susceptible genotypes at both the stages $(6.81,4.90$ and $3.17 \%)$, respectively.

The total silica content was 2-3 folds more in highly resistant (Sambha mashsuri, NVSR411) and moderately resistant (NVSR-355, NVSR- 389) genotypes compared to susceptible genotype (GR-11) at 7 days after infection. The higher level of total silica content may indicate that the activation of host defensive system or rapid rate of their synthesis induced by the pathogen leading to tissue necrosis and may be responsible for the inhibition of the growth and multiplication of the pathogen.

Biochemical constituent's changes were analyzed at pre and post inoculation stage (7 days after inoculation of $S$. oryzae) of eight rice genotypes showing resistant, moderately resistant and susceptible reaction to sheath rot. Total soluble sugar increased by range of 3.64 to $31.33 \%$, reducing sugar increased by range of 4.19 to $28.11 \%$ and non-reducing sugar increased by range of 2.95 to $35.11 \%$. Total phenol increased by range of 15.73 to 
$42.56 \%$, total soluble protein increased by range of 6.95 to $31.12 \%$ and total silica increased by range of 3.17 to 8.36 per cent due to sheath rot disease in different rice genotypes.

Table.1 Disease severity rating scales for sheath rot

\begin{tabular}{|c|c|c|}
\hline Score & Description & Disease reaction \\
\hline $\mathbf{0}$ & No lesion/ spot on flag leaf sheath. & Highly Resistant \\
\hline 1 & $\begin{array}{l}\text { Spots visible on the tillers upon very careful } \\
\text { examination (less than } 1 \text { per cent flag leaf sheath area } \\
\text { covered). }\end{array}$ & Resistant \\
\hline 3 & $\begin{array}{l}\text { Spots visible on the tillers upon careful examination } \\
\text { ( } 1 \text { to } 5 \text { per cent flag leaf sheath area covered). }\end{array}$ & Moderately resistant \\
\hline 5 & $\begin{array}{l}\text { Spots easily visible on tillers ( } 6 \text { to } 25 \text { per cent flag } \\
\text { leaf sheath area covered). }\end{array}$ & $\begin{array}{l}\text { Moderately } \\
\text { susceptible }\end{array}$ \\
\hline 7 & $\begin{array}{l}\text { Spots present on almost whole the tillers parts ( } 26 \text { to } \\
50 \text { per cent flag leaf sheath area covered). }\end{array}$ & Susceptible \\
\hline 9 & $\begin{array}{l}\text { Spots very common on whole tillers parts ( } 51 \text { to } 100 \\
\text { per cent flag leaf sheath area covered) death of plants } \\
\text { common, reduced severe yield loss. }\end{array}$ & Highly susceptible \\
\hline
\end{tabular}

Table.2 Reactions of the rice entries from advance genotypes against sheath rot of rice

\begin{tabular}{|c|c|c|c|c|}
\hline Score & Description & $\begin{array}{l}\text { Disease } \\
\text { reaction }\end{array}$ & $\begin{array}{c}\text { Total } \\
\text { genotypes }\end{array}$ & Name of genotypes \\
\hline 0 & $\begin{array}{l}\text { No lesions/ spot on flag } \\
\text { leaf sheath. }\end{array}$ & $\begin{array}{l}\text { Highly } \\
\text { Resistant }\end{array}$ & 0 & NIL \\
\hline 1 & $\begin{array}{l}\text { less than } 1 \text { per cent flag } \\
\text { leaf sheath area covered }\end{array}$ & Resistant & 4 & $\begin{array}{l}\text { NVSR-317,NVSR-411,NVSR-405 and Sambha } \\
\text { mahsuri }\end{array}$ \\
\hline 3 & $\begin{array}{l}1 \text { to } 5 \text { per cent flag leaf } \\
\text { sheath area covered }\end{array}$ & $\begin{array}{l}\text { Moderately } \\
\text { resistant }\end{array}$ & 23 & $\begin{array}{l}\text { NVSR-348, NVSR-350, NVSR-355, NVSR-2101, } \\
\text { NVSR-2103, NVSR-328, NVSR-329, NVSR-2528, } \\
\text { NVSR-2565, NVSR-2566, NVSR-330, NVSR-331, } \\
\text { NVSR-335, NVSR-338, NVSR-360, NVSR-364, } \\
\text { NVSR-365, NVSR-370, NVSR-374, NVSR-384, } \\
\text { NVSR-389, NVSR-2435 and NVSR-406 }\end{array}$ \\
\hline 5 & $\begin{array}{l}6 \text { to } 25 \text { per cent flag leaf } \\
\text { sheath area covered }\end{array}$ & $\begin{array}{l}\text { Moderately } \\
\text { susceptible }\end{array}$ & 3 & NVSR-2526,NVSR-367, NVSR-407 \\
\hline 7 & $\begin{array}{l}26 \text { to } 50 \text { per cent flag } \\
\text { leaf sheath area covered }\end{array}$ & Susceptible & 2 & GR-11 and TN-1 \\
\hline 9 & $\begin{array}{l}51 \text { to } 100 \text { per cent flag } \\
\text { leaf sheath area covered }\end{array}$ & $\begin{array}{c}\text { Highly } \\
\text { susceptible }\end{array}$ & 0 & NIL \\
\hline
\end{tabular}


Table.3 Total soluble, reducing and non reducing sugar content in resistant and susceptible rice genotypes against sheath rot of rice caused by Sarocladium oryzae

\begin{tabular}{|c|c|c|c|c|c|c|c|c|c|c|}
\hline \multirow[t]{2}{*}{$\begin{array}{l}\text { Treat. } \\
\text { No. }\end{array}$} & \multirow[t]{2}{*}{$\begin{array}{l}\text { Name of } \\
\text { Genotypes }\end{array}$} & \multicolumn{3}{|c|}{$\begin{array}{l}\text { Total soluble sugar } \\
\text { (mg/g fresh weight) }\end{array}$} & \multicolumn{3}{|c|}{$\begin{array}{l}\text { Reducing sugar } \\
\text { (mg/g fresh weight) }\end{array}$} & \multicolumn{3}{|c|}{$\begin{array}{l}\text { Non reducing sugar } \\
\text { (mg/g fresh weight) }\end{array}$} \\
\hline & & $\begin{array}{c}\text { Pre } \\
\text { inoculated }\end{array}$ & $\begin{array}{c}\text { Post } \\
\text { Inoculated (7 } \\
\text { DAI) }\end{array}$ & $\begin{array}{c}\text { Per cent } \\
\text { decrease } \\
\text { over pre } \\
\text { inoculated }\end{array}$ & $\begin{array}{c}\text { Pre } \\
\text { inoculated }\end{array}$ & $\begin{array}{l}\text { Post } \\
\text { Inoculated (7 } \\
\text { DAI) }\end{array}$ & $\begin{array}{l}\text { Per cent decrease } \\
\text { over pre inoculated }\end{array}$ & $\begin{array}{c}\text { Pre } \\
\text { inoculated }\end{array}$ & $\begin{array}{c}\text { Post } \\
\text { Inoculated (7 } \\
\text { DAI) }\end{array}$ & $\begin{array}{l}\text { Per cent decrease } \\
\text { over pre inoculated }\end{array}$ \\
\hline & \multicolumn{10}{|c|}{ Resistant genotypes } \\
\hline $\mathbf{T}_{1}$ & NVSR-317 & 7.15 & 6.34 & 11.40 & 3.21 & 2.89 & 10.05 & 3.94 & 3.45 & 12.49 \\
\hline $\mathbf{T}_{2}$ & NVSR-411 & 4.81 & 4.63 & 3.64 & 2.67 & 2.56 & 4.19 & 2.14 & 2.08 & 2.95 \\
\hline \multirow[t]{3}{*}{$\mathbf{T}_{3}$} & NVSR-405 & 8.87 & 7.49 & 15.50 & 4.57 & 3.96 & 13.37 & 4.30 & 3.53 & 17.76 \\
\hline & Mean & 6.94 & 6.15 & 10.18 & 3.48 & 3.13 & 9.20 & 3.46 & 3.02 & 11.07 \\
\hline & \multicolumn{10}{|c|}{ Moderately resistant genotypes } \\
\hline $\mathbf{T}_{4}$ & NVSR-355 & 10.48 & 8.81 & 15.91 & 5.51 & 4.75 & 13.76 & 4.98 & 4.06 & 18.30 \\
\hline $\mathbf{T}_{5}$ & NVSR-2565 & 12.73 & 10.21 & 19.78 & 6.58 & 5.22 & 20.56 & 6.15 & 4.99 & 18.94 \\
\hline \multirow{3}{*}{$\mathbf{T}_{6}$} & NVSR-389 & 10.78 & 8.84 & 17.97 & 5.95 & 4.94 & 16.88 & 4.83 & 3.90 & 19.32 \\
\hline & Mean & 11.33 & 9.29 & 17.89 & 6.01 & 4.97 & 17.07 & 5.32 & 4.32 & 18.85 \\
\hline & \multicolumn{10}{|l|}{ Checks } \\
\hline $\mathbf{T}_{7}$ & Sambha Mahsuri & 5.28 & 4.82 & 8.73 & 2.89 & 2.67 & 7.42 & 2.39 & 2.14 & 10.31 \\
\hline $\mathbf{T}_{8}$ & GR-11 & 25.50 & 17.51 & 31.33 & 13.80 & 9.92 & 28.11 & 11.69 & 7.59 & 35.11 \\
\hline & SEm+/- & 0.10 & 0.07 & & 0.07 & 0.07 & & 0.13 & 0.10 & \\
\hline & CD $5 \%$ & 0.31 & 0.20 & & 0.21 & 0.20 & & 0.38 & 0.29 & \\
\hline & CV \% & 1.69 & 1.39 & & 2.20 & 2.52 & & 4.40 & 4.27 & \\
\hline
\end{tabular}


Table.4 Total phenol, total soluble proteins and total silica content in resistant and susceptible rice genotypes against sheath rot of rice caused by Sarocladium oryzae

\begin{tabular}{|c|c|c|c|c|c|c|c|c|c|c|}
\hline \multirow[t]{2}{*}{$\begin{array}{l}\text { Treat. } \\
\text { No. }\end{array}$} & \multirow[t]{2}{*}{ Name of Genotypes } & \multicolumn{3}{|c|}{$\begin{array}{c}\text { Total phenol } \\
\text { (mg/g fresh weight) }\end{array}$} & \multicolumn{3}{|c|}{$\begin{array}{l}\text { Total soluble protein } \\
\text { (mg/g fresh weight) }\end{array}$} & \multicolumn{3}{|c|}{$\begin{array}{l}\text { Total silica } \\
(\%)\end{array}$} \\
\hline & & $\begin{array}{c}\text { Pre } \\
\text { inoculated }\end{array}$ & $\begin{array}{c}\text { Post } \\
\text { Inoculated (7 } \\
\text { DAI) }\end{array}$ & $\begin{array}{c}\text { Per cent } \\
\text { increase over } \\
\text { pre } \\
\text { inoculated }\end{array}$ & $\begin{array}{c}\text { Pre } \\
\text { inoculated }\end{array}$ & $\begin{array}{c}\text { Post } \\
\text { Inoculated (7 } \\
\text { DAI) }\end{array}$ & $\begin{array}{c}\text { Per cent } \\
\text { decrease over } \\
\text { pre } \\
\text { inoculated }\end{array}$ & $\begin{array}{c}\text { Pre } \\
\text { inoculated }\end{array}$ & $\begin{array}{c}\text { Post } \\
\text { Inoculated (7 } \\
\text { DAI) }\end{array}$ & $\begin{array}{c}\text { Per cent } \\
\text { increase over } \\
\text { pre } \\
\text { inoculated }\end{array}$ \\
\hline & \multicolumn{10}{|c|}{ Resistant genotypes } \\
\hline $\mathbf{T}_{1}$ & NVSR-317 & 1.38 & 1.87 & 35.92 & 9.69 & 8.56 & 11.65 & 3.64 & 3.91 & 7.41 \\
\hline $\mathbf{T}_{2}$ & NVSR-411 & 1.45 & 2.02 & 39.73 & 9.13 & 8.50 & 6.95 & 3.65 & 3.93 & 7.68 \\
\hline \multirow[t]{3}{*}{$\mathbf{T}_{\mathbf{3}}$} & NVSR-405 & 1.07 & 1.33 & 23.99 & 11.82 & 9.93 & 15.92 & 3.63 & 3.82 & 5.33 \\
\hline & Mean & 1.38 & 1.87 & 35.92 & 9.69 & 8.56 & 11.65 & 3.64 & 3.89 & 6.81 \\
\hline & \multicolumn{10}{|c|}{ Moderately resistant genotypes } \\
\hline $\mathbf{T}_{4}$ & NVSR-355 & 0.97 & 1.17 & 20.33 & 15.02 & 12.61 & 16.07 & 3.45 & 3.65 & 5.60 \\
\hline $\mathbf{T}_{5}$ & NVSR-2565 & 0.76 & 0.89 & 16.67 & 15.19 & 11.70 & 22.95 & 3.28 & 3.42 & 4.27 \\
\hline \multirow[t]{3}{*}{$\mathbf{T}_{6}$} & NVSR-389 & 0.93 & 1.09 & 17.45 & 15.17 & 12.09 & 20.32 & 3.44 & 3.61 & 4.84 \\
\hline & Mean & 0.97 & 1.17 & 20.33 & 15.02 & 12.61 & 16.07 & 3.39 & 3.56 & 4.90 \\
\hline & \multicolumn{10}{|l|}{ Checks } \\
\hline $\mathbf{T}_{7}$ & Sambha Mahsuri (RC) & 1.52 & 2.16 & 42.56 & 9.20 & 8.37 & 9.08 & 3.71 & 4.02 & 8.36 \\
\hline \multirow[t]{4}{*}{$\mathbf{T}_{8}$} & GR-11 (SC) & 0.70 & 0.82 & 15.73 & 17.10 & 11.78 & 31.12 & 3.15 & 3.25 & 3.17 \\
\hline & SEm+/- & 0.02 & 0.03 & & 0.08 & 0.07 & & 0.02 & 0.02 & \\
\hline & CD $5 \%$ & 0.07 & 0.08 & & 0.25 & 0.21 & & 0.06 & 0.07 & \\
\hline & CV \% & 3.66 & 3.49 & & 1.14 & 1.21 & & 0.97 & 1.13 & \\
\hline
\end{tabular}



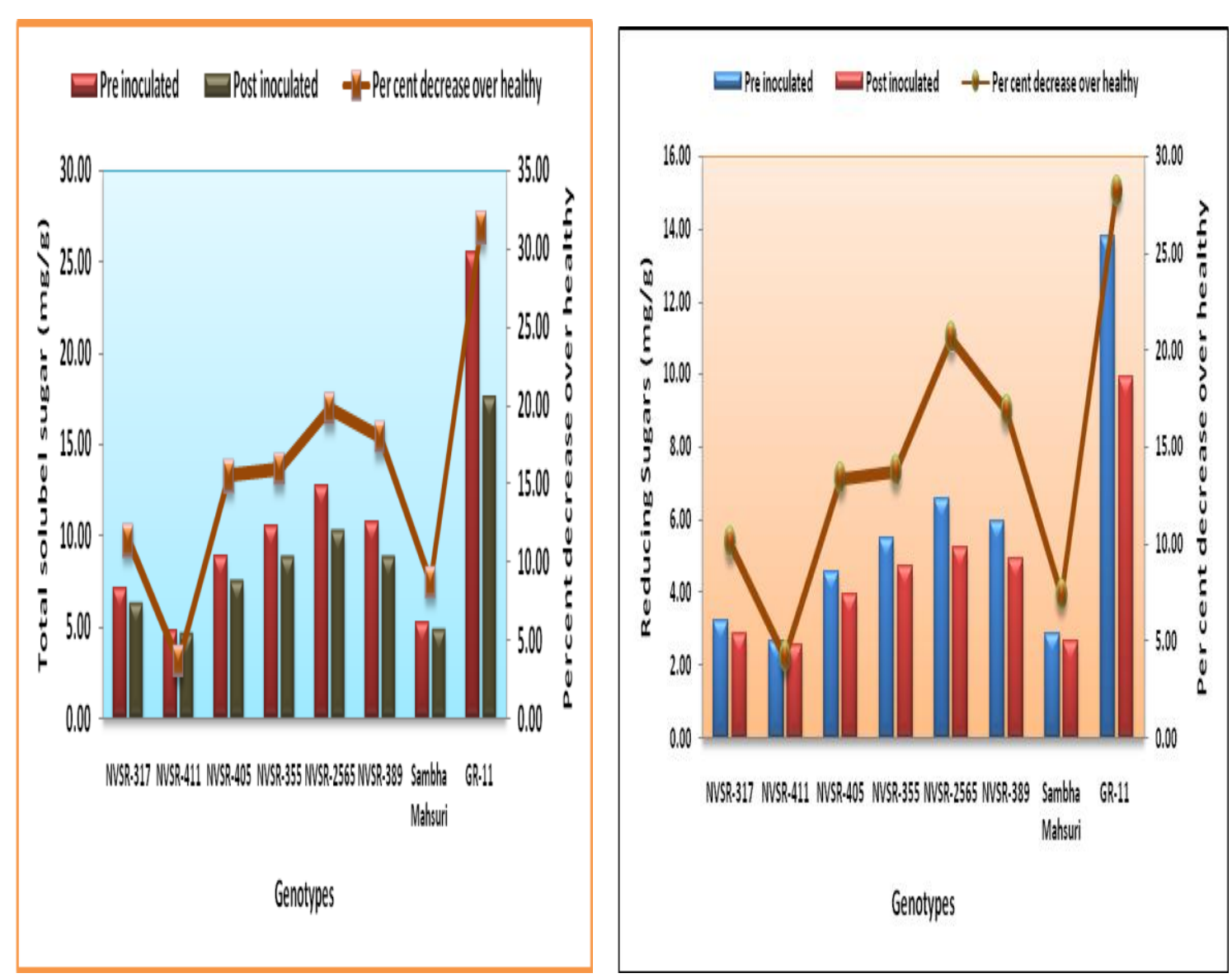

Fig.1: Total soluble sugar content in different rice genotypes against sheath rot caused by Sarocladium oryzae
Fig. 2: Reducing sugar content in different rice genotypes against sheath rot caused by Sarocladium oryzae

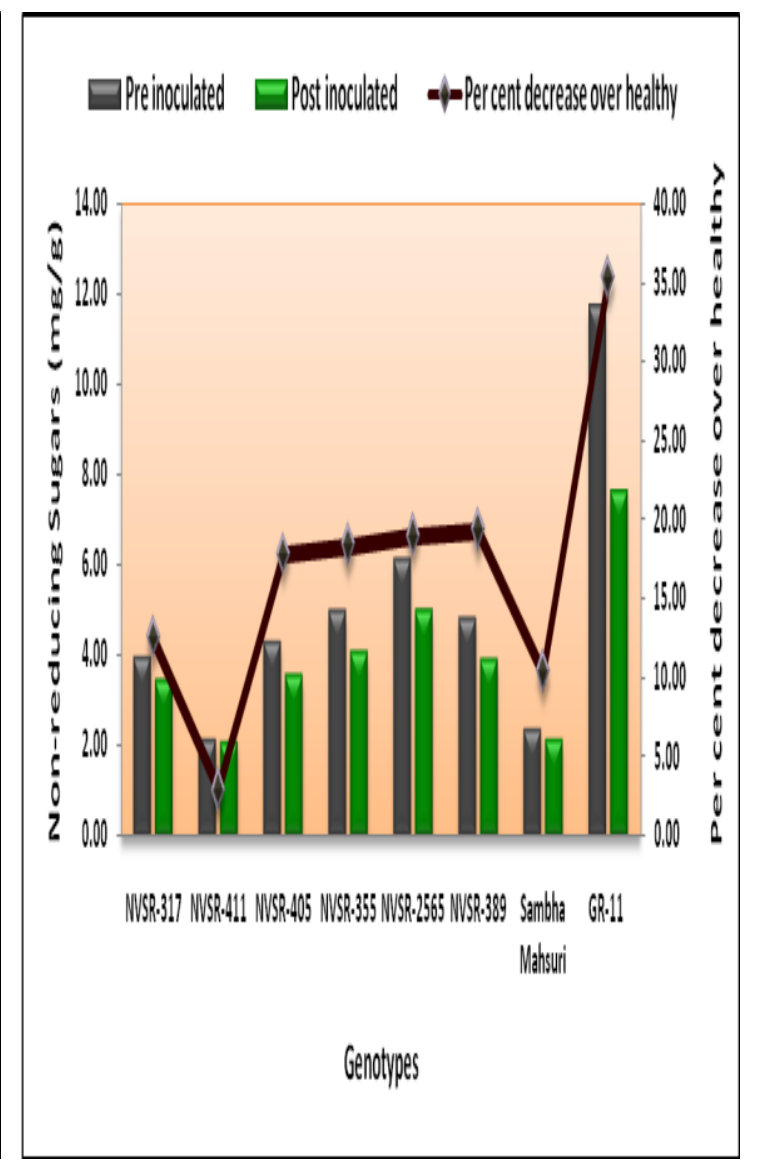

Fig. 3: Non-reducing sugar content in different rice genotypes against sheath rot caused by Sarocladium oryzae 


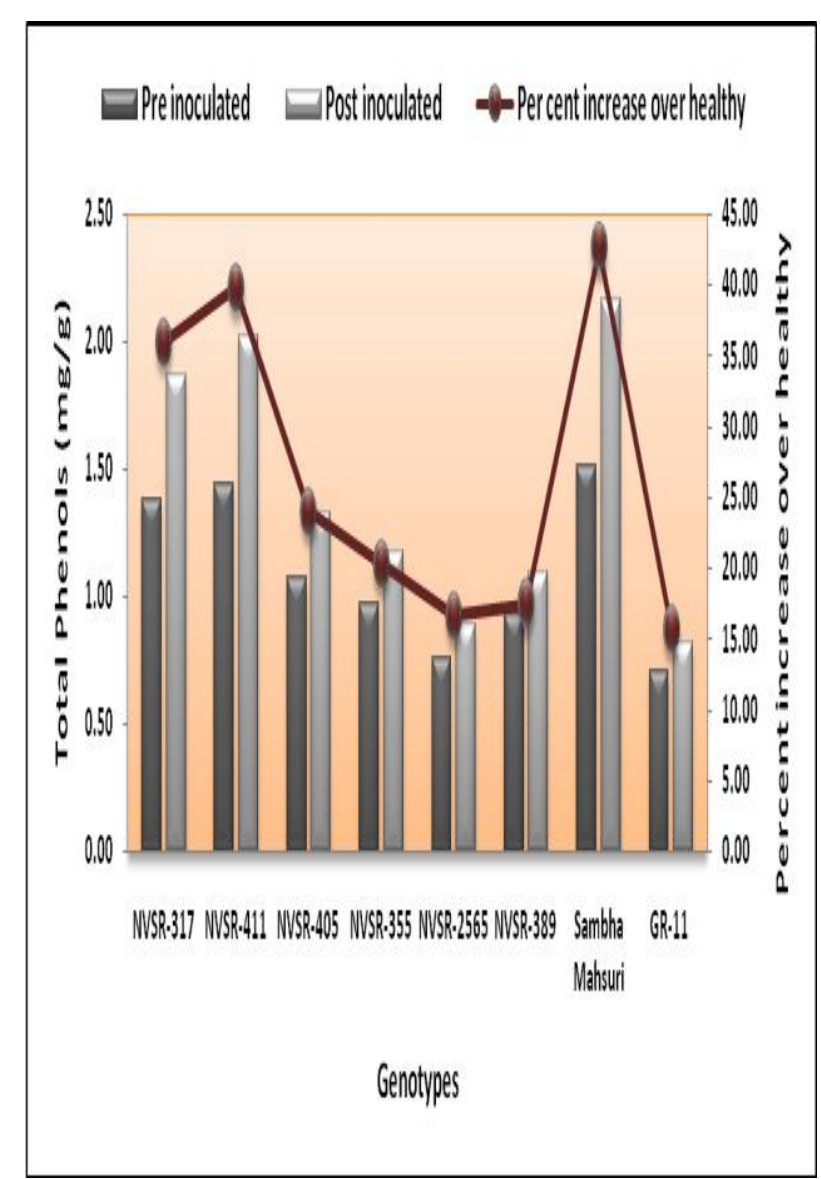

Fig. 4: Total phenol content in different rice genotypes against sheath rot caused by Sarocladium oryzae

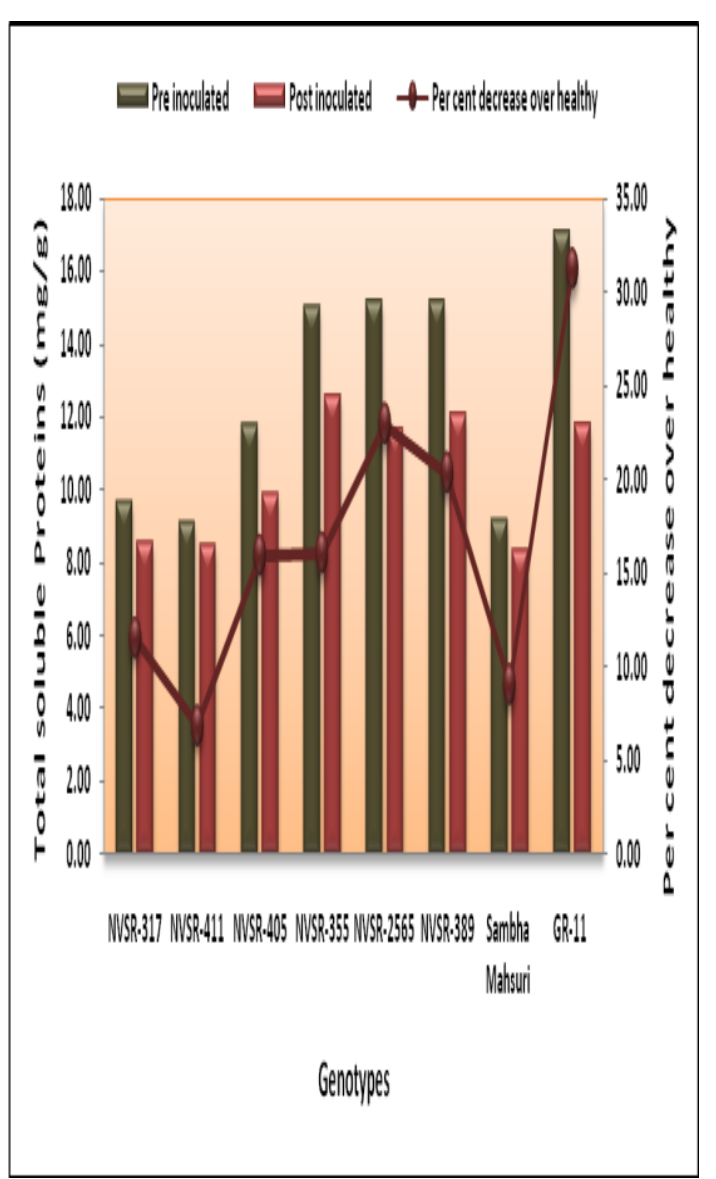

Fig. 5: Total soluble protein content in different rice genotypes against sheath rot caused by Sarocladium oryzae $\square$ Preinoculated $\square$ Postinoculated =-Percentincrease over heathy

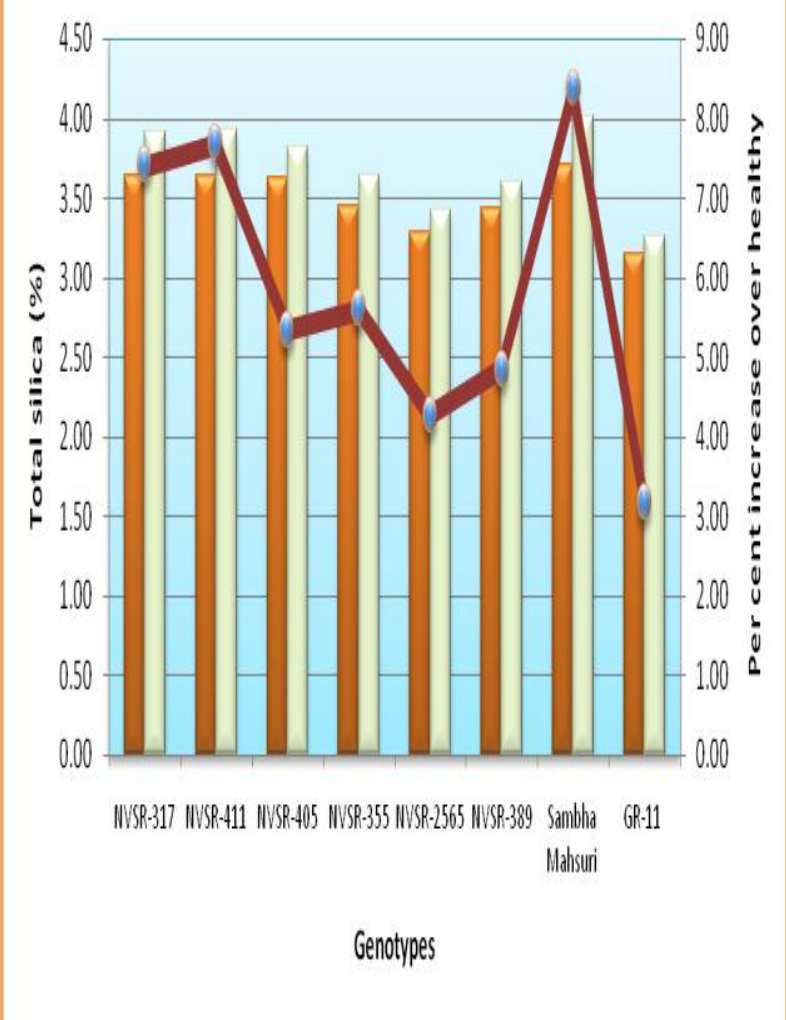

Fig. 6: Total silica content in different rice genotypes against sheath rot caused by Sarocladium oryzae 
In conclusion, the results of present investigation reveal that, resistant rice genotypes NVSR-317, NVSR-405 and NVSR-411 contain lower levels of total soluble sugar, reducing sugar, non-reducing sugar and total soluble protein content and higher levels of total phenol and total silica content than the susceptible genotypes (GR11). It indicates that, these defensive compounds contributing towards the sheath rot resistance. Such defense mechanism in the resistant is activated immediately after inoculation or infection by $S$. oryzae and same mechanism may be operated in susceptible genotypes but it starts quite slowly and reaches comparatively low level. These genotypes possibly serve as resistance source for further development of resistant varieties.

The present results are in conformity with findings of Gopalakrishnan et al., (2010) noticed a progressive and significant reduction in total sugar, reducing sugar and non reducing sugar content of rice of three popular cultivars, CO-43, ASD-18 and ADTRH-1 with varying degree of infection caused by Sarocladium oryzae. The similar trend was noticed in the case of starch and protein content also. However, there was an increase in total phenol content of infected samples compared to pre inoculated samples in all the three cultivar samples tested. The increase in phenol content due to Sarocladium oryzae infection ranged from 15.74 to 70.78 per cent and being proportional to per cent Sarocladium oryzae infection. This might be due to the accumulation of phenols by host in response to the invasion by Sarocladium oryzae.

Yesu Raja and Syamala (2012) found the decreased contents of total soluble, reducing and non-reducing sugars in rice plants due to infection by $S$. oryzae.

Singh et al., (2017) screened twenty aromatic (Joha) rice germplasms against sheath rot disease. It was recorded that, the highest content of phenol and lowest content of total soluble sugar, total protein and starch content were found in highly resistant cultivar. The results revealed that these biochemical parameters were directly related with resistance and susceptibility of the rice cultivars.

\section{References}

Bray, H. G. and Thorpe W.V. (1954). Estimation of phenol. Methods Biochemical Annulus, 1: 27-52.

Gopalakrishnan, C., Kamalakannan, A. and Valluvaparidasan, V. (2010). Effect of seed-borne Sarocladium oryzae the inciting of rice sheath rot on rice seed quality. Journal of Plant Protection Research, 50(1): 98-102.

Hedge, J. E. and Hofreiter, B. T. (1962). In: Carbohydrates chemistry, (17, eds. Whistler, R.L. and Bemiller, J.N.) Academic Press, New York.

IRRI (2013). Standard of evaluation system for rice. The international rice testing programme. Genetic resources centre, International Rice Research Institute. Manilla, Philippines, Pp: 20-21.

Lowry, O. H., Rosebrough, N. J., Farr, A. L. and Randall, R. J. (1951). Estimation of protein. Journal of Biological Chemistry, Pp: 193-265.

Phookan, A. K. and Hazarika, D. K. (1992). Distribution of sheath rot (ShR) in six agroclimatic zones of Assam, India. Indian Rice Research News. 17: 17.

Sadasivam, S. and Manickam, A. (1992). In: Biochemical methods for Agriculture Science, Wiley Eastern Limited, New Delhi, Pp. 11-12.

Singh, M., Das, B. C., Kalita, P. and Ahmed, A. A. (2017). Evaluation of some genotypes of aromatic (Joha) rice for its resistance and susceptibility against sheath rot disease based on physiological parameters. International 
Journal of Basic and Applied Biology, 4(2): 82-84.

Staskawicz, B. J., Ausubel, F. M., Baker, B. Yesu Raja, I. and Syamala, M. (2012). J., Ellis, J. G., \& Jones, J. D. C. (1997). Molecular genetics of plant disease resistance. Science, 268, 661-667.

Thimmaiah, S. R. (1999). Standard methods of biochemical analysis. Kalyani Publishers, New Delhi, Pp.: 1-545. Physiological alterations induced by plant extracts in rice plants inoculated with Sarocladium oryzae. Madras Agriculture Journal, 99(1-3): 107-115.

\section{How to cite this article:}

Nalawade, S. V., P. R. Patel and Patil, V. A. 2020. Biochemical Constituents Variation in Resistant and Susceptible Rice Genotypes against Sheath Rot Disease of Rice. Int.J.Curr.Microbiol.App.Sci. 9(05): 729-742. doi: https://doi.org/10.20546/ijcmas.2020.905.081 